\title{
Pola Asuh Autoritatif dan Jenis Kelamin sebagai Prediktor Big Five Personality Factors: Implikasinya Bagi Pelayanan Bimbingan dan Konseling
}

\author{
Zummy Anselmus Dami, Santi Curniati \\ Program Studi Bimbingan dan Konseling, Fakultas Keguruan dan Ilmu Pendidikan, \\ Universitas Persatuan Guru 1945 NTT, Jl. Perintis Kemerdekaan III/40, Kupang, Nusa Tenggara Timur, \\ Indonesia 85228 \\ E-mail: zummydami82@gmail.com
}

Artikel diterima: 22 November 2018; direvisi: 30 Januari 2019; disetujui: 31 Januari 2019

\begin{abstract}
The study aimed to determine the authoritative parenting; gender; gender and the influence of authoritative parenting significantly toward big five personality. This quantitative research with descriptive analysis techniques of Multivariate Analysis of Covariance (MANCOVA) test involved 62 students of eleventh grade of Sekolah Menengah Atas Negeri 2 Kupang as a respondent. Data collection technique used the scale instrument of Parental Authority Questionnaire and the International Personality Item Pool. The results showed that: (1) there was no significant influence of parental authority on the subjects's big five personality, except extraversion; (2) there was no significant effect of gender on subjects's big five personality; and (3) there was no significant effect of gender interaction and authoritative parenting on subject's the big five personality.
\end{abstract}

Keywords: authoritative parenting style; gender; big five personality factors

\begin{abstract}
Abstrak: Penelitian ini bertujuan untuk mengetahui gaya pola asuh autoritatif; jenis kelamin; dan interaksi jenis kelamin serta pengaruh gaya pola asuh ototitatif secara signifikan terhadap big five personality. Penelitian kuantitatif dengan teknik analisis deskriptif uji MANCOVA ini melibatkan 62 siswa kelas XI Sekolah Menengah Atas (SMA) Negeri 2 Kupang sebagai responden. Data dikumpulkan dengan instrumen skala Parental Authority Questionnaire dan International Personality Item Pool. Hasil penelitian menunjukkan bahwa: (1) tidak ada pengaruh signifikan pola asuh autoritatif orangtua terhadap big five personality subjek, kecuali extraversion; (2) tidak ada pengaruh signifikan jenis kelamin terhadap big five personality subjek; dan (3) tidak ada pengaruh signifikan interaksi jenis kelamin dan pola asuh autoritatif terhadap big five personality subjek.
\end{abstract}

Kata kunci: pola asuh autoritatif; jenis kelamin; lima faktor kepribadian

Kepribadian adalah karakteristik yang kompleks dan mencerminkan pola hidup individu. Kepribadian merupakan suatu pola individu merasakan; berpikir; dan berperilaku. Kepribadian adalah ciri/ karakteristik/sifat khas dari diri individu yang bersumber dari bentukan-bentukan yang diterima dari lingkungan, yaitu keluarga, ketika individu masih kecil dan juga bawaan sejak lahir. Kepribadian yang dimiliki individu akan berpengaruh terhadap akhlak; moral; budi pekerti; etika; dan estetika individu tersebut ketika berinteraksi dan berkomunikasi dengan individu lain dalam kehidupan sehari-hari di manapun dia berada (Sjarkawi, 2008). Kepribadian individu dalam konteks penelitian ini adalah kepribadian siswa terdiri dari lima faktor, yaitu: extraversion; agreeableness; conscientiousness; neuroticism/emotional stability; dan openness to experience (Savitha \& Venkatachalam, 2016). 
Di dalam perspektif layanan bimbingan dan konseling: (1) siswa SMA yang memiliki ciri kepribadian openness to experience dan conscientiousness cenderung tidak mudah untuk mengalami kebimbangan karier; sedangkanmerekayang memilikiciriextraversion; neuroticsm danagreeableness cenderung mengalami kebimbangan karier (Utami, Grasiaswaty, \& Akmal, 2018), walaupun dalam pengambilan keputusan karier siswa laki-laki dan perempuan menunjukkan persamaan (Lounsbury, Hutchens, \& Loveland, 2005); (2) hasil penelitian pada siswa Sekolah Menengah Pertama (SMP) di Kecamatan Prambanan Klaten, menunjukkan bahwa siswa yang memiliki ciri conscientiousness; extraversion; openness to experience; agreeableness; dan neuroticsm tidak berpengaruh terhadap prestasi akademik (Purwanta, 2012); sebaliknya hasil penelitian lain menunjukkan bahwa dimensi neuroticsm; extraversion; dan conscientiousness berpengaruh secara signifikan terhadap prestasi akademik (Rosito, 2018);(3) siswa dengan cirikepribadian conscientiousness; openness to experience; extraversion; dan neuroticsm memiliki motivasi belajar, sedangkan siswa yang agreeableness, tidak memiliki motivasi belajar di sekolah (Raza \& Shah, 2017); (4) hasil penelitian di SMP Islam Sabilal Muhtadin Banjarmasin ditemukan siswa yang memiliki dimensi kepribadian openness to experience; conscientiousness; extraversion; dan neuroticsm tidak memiliki peranan signifikan terhadap kecenderungan bullying pada remaja, sedangkan siswa yang berkepribadian agreeableness memiliki kecenderungan bullying (Ramadhani, Anward, \& Rachmah, 2016); (5) Terdapat hubungan antara tipe kepribadian dalam big five factor personality dengan perilaku narsistik pada siswa kelas X SMA Muhammadiyah 2 Yogyakarta. Bentuk perilaku narsistik yang banyak ditemukan pada siswa adalah kecenderungan untuk lebih merasakan cemas; mudah marah; memusuhi orang; tidak suka dikritik; keadaan membela diri; eksploitatif; merasa bahwa dirinya hebat; imajinatif; menganggap diri mereka unik; curiga terhadap orang lain; perfeksionis; serta membutuhkan banyak pujian dan senang memamerkan diri (Hardiani, 2014).

Orangtua memiliki peran penting dan strategis dalam menentukan kemana arah kepribadian anak akan dibentuk (Djamarah, 2014; George \& Jones, 1996; Mullins, 2007). Hal ini dikarenakan orangtua adalah orang yang pertama dan mempunyai banyak waktu dengan anak dalam keluarga. Orangtua adalah pendidik kodrati bagi anak di dalam keluarga. Pengetahuan orangtua terhadap fase-fase pertumbuhan dan perkembangan anak sangat menentukan terjadinya komunikasi dan interaksi yang baik antara anak dan orangtua, dengan demikian apa yang diinginkan orangtua dalam pembentukan kepribadian anak menuju kepribadian yang mandiri dapat tercapai (Anggraini, Hartuti, \& Sholihah, 2018). Peran orangtua harus ditekankan sesuai dengan pola asuh (Desmita, 2011). Ada empat pola asuh orangtua, yaitu: authoritarian; authoritative; permissive; dan neglectful (Baumrind, 199; Sidhu, Kaus, \& Sharma, 2016).

Hasil penelitian menunjukkan bahwa pola asuh orangtua memiliki pengaruh yang besar terhadap kepribadian dan ciri kepribadian anak (Baldwin, McIntyre, \& Hardaway, 2007). Dari keempat pola asuh orangtua, penelitian ini hanya menginvestigasi pengaruh pola asuh autoritatif terhadap big five personality factors. Pola asuh autoritatif dipilih karena banyak dipraktikkan dan diterima oleh remaja (Garcia \& Santiago, 2017). Pola asuh autoritatif juga diyakini berakibat positif bagi perkembangan diri anak. Selama usia remaja, pola asuh autoritatif secara konsisten berhubungan dengan kematangan sosial anak, sikap percaya diri tinggi, standar moral terinternalisasi, prestasi akademik tinggi, dan tanggung jawab pada tugas (Respati, Yulianto, \& Widiana, 2006). Pola asuh autoritatif merupakan gabungan antara pola asuh permisif dan otoriter, kedudukan orangtua dan anak sejajar, suatu keputusan diambil bersama dengan pertimbangan kedua belah pihak. Anak diberi kebebasan yang bertanggungjawab, artinya apa yang dilakukan anak tetap harus dibawah pengawasan orangtua dan dapat dipertanggungjawabkan secara moral (Dariyo, 2003). Pola asuh autoritatif orangtua juga berpengaruh terhadap pemilihan karier siswa di sekolah (Safitri, 2012); prestasi siswa di sekolah (Hidayanti, 2017); konsep diri siswa di sekolah (Septiani, 2017); kemampuan pengambilan keputusan karier siswa di sekolah (Amalia, 2017); dan kepribadian siswa di sekolah (Anggraini dkk., 2018).

Pola asuh orangtua yang menerapkan aturan dengan tidak konsisten dan orangtua yang cenderung perfeksionis juga dapat memunculkan perilaku agresif pada anak, sehingga terjadi kekerasan fisik dan verbal (Rahayu, 2018; Wiyani, 2014). Sebaliknya, pola asuh autoritatif orangtua dapat menekan 
tingkat keagresifan siswa di sekolah karena remaja belajar dari lingkungan yang diciptakan oleh orangtua yang memberikan pengertian dan kemampuan untuk membangun toleransi dengan lingkungan di sekitarnya (Diponegoro, 2013). Pola asuh autoritatif juga memengaruhi kedisiplinan siswa pada peratutan tata tertib sekolah, hal ini karena gaya pengasuhan autoritatif menjadikan seorang anak dapat mengetahui dan memahami apabila tindakannya salah dan dapat mengetahui solusi yang baik dari bimbingan orangtua (Antoni, 2014). Sebuah penelitian mengenai hubungan antara pola asuh orangtua dengan kenakalan remaja di SMA Negeri 8 Surakarta menunjukkan bahwa: $8,8 \%$ atau delapan orang responden yang diasuh dengan pola permisif memiliki tingkat kenakalan remaja yang masuk kategori tinggi; $26,4 \%$ atau 24 responden yang diasuh dengan pola asuh otoriter memiliki tingkat kenakalan remaja sedang; dan 38,5\% atau 35 responden yang diasuh menggunakan pola asuh autoritatif memiliki tingkat kenakalan biasa (Sunaryanti, 2016).

Beberapa hasil penelitian menunjukkan pengaruh pola asuh autoritatif orangtua terhadap lima faktor kepribadian tidak konsisten. Gaya pola asuh demokratis atau autoritatif memiliki hubungan yang positif dan signifikan dengan pengembangan kepribadian remaja (Sravanthi, 2007). Pola asuh

Tabel 1 Hasil Penelitian Sebelumnya Mengenai Signifikansi Pola Asuh Autoritatif Terhadap Big Five Personality

\begin{tabular}{|c|c|c|c|c|}
\hline No. & $\begin{array}{c}\text { Big Five } \\
\text { Personality Factors }\end{array}$ & Signifikan & Tidak Signifikan & Peneliti \\
\hline \multirow[t]{6}{*}{1} & \multirow[t]{6}{*}{ Extraversion } & $\sqrt{ }$ & & (Mize \& Pettit, 1997) \\
\hline & & $\sqrt{ }$ & & (Sravanthi, 2007) \\
\hline & & $\sqrt{ }$ & & (Kilonzo, 2017) \\
\hline & & & $\sqrt{ }$ & $\begin{array}{l}\text { (Maddahi, Javidi, Samadzadeh, \& } \\
\text { Amini, 2012) }\end{array}$ \\
\hline & & & $\sqrt{ }$ & (Ghani, Roeswardi, \& Aziz, 2014) \\
\hline & & & $\sqrt{ }$ & (Savitha \& Venkatachalam, 2016) \\
\hline \multirow[t]{5}{*}{2} & \multirow[t]{5}{*}{ Conscientiousness } & $\sqrt{ }$ & & (Maddahi dkk., 2012) \\
\hline & & $\sqrt{ }$ & & (Dordi \& Pol, 2018) \\
\hline & & & $\sqrt{ }$ & (Turner, Chandler, \& Heffer, 2009) \\
\hline & & & $\sqrt{ }$ & (Ghani dkk., 2014) \\
\hline & & & $\sqrt{ }$ & (Savitha \& Venkatachalam, 2016) \\
\hline \multirow[t]{5}{*}{3} & \multirow{5}{*}{$\begin{array}{l}\text { Openness to } \\
\text { experience }\end{array}$} & $\sqrt{ }$ & & (Farbstein, 2011) \\
\hline & & $\sqrt{ }$ & & (Savitha \& Venkatachalam, 2016) \\
\hline & & $\sqrt{ }$ & & (Dordi \& Pol, 2018) \\
\hline & & & $\sqrt{ }$ & (Maddahi dkk., 2012) \\
\hline & & & $\sqrt{ }$ & (Ghani dkk., 2014) \\
\hline \multirow[t]{5}{*}{4} & \multirow{5}{*}{$\begin{array}{l}\text { Neuroticism/ } \\
\text { emotional stability }\end{array}$} & $\sqrt{ }$ & & (Sravanthi, 2007) \\
\hline & & $\sqrt{ }$ & & (Savitha \& Venkatachalam, 2016) \\
\hline & & & $\sqrt{ }$ & (Abdi, Jalali, \& Mirmehdy, 2010) \\
\hline & & & $\sqrt{ }$ & (Ghani dkk., 2014) \\
\hline & & & $\sqrt{ }$ & $\begin{array}{l}\text { (Bahrami, Dolatshahi, Pourshahbaz, } \\
\& \text { Mohammadkhani, 2017) }\end{array}$ \\
\hline \multirow[t]{5}{*}{5} & \multirow[t]{5}{*}{ Agreeableness } & $\sqrt{ }$ & & (Sravanthi, 2007) \\
\hline & & $\sqrt{ }$ & & (Kilonzo, 2017) \\
\hline & & & $\sqrt{ }$ & (Maddahi dkk., 2012) \\
\hline & & & $\sqrt{ }$ & (Ghani dkk., 2014) \\
\hline & & & $\sqrt{ }$ & (Savitha \& Venkatachalam, 2016) \\
\hline
\end{tabular}


orangtua juga memiliki pengaruh yang rendah terhadap ciri-ciri kepribadian (Frazier, 2018). Secara terperinci hasil penelitian yang inkonsisten mengenai pengaruh pola asuh orangtua gaya autoritatif pada lima faktor kepribadian disajikan pada tabel 1.

Berkaitan dengan pengaruh jenis kelamin terhadap kepribadian, hasil penelitian membuktikan bahwa untuk semua pola asuh, jenis kelamin laki-laki memiliki perkembangan kepribadian lebih baik dibandingkan jenis kelamin perempuan (Sravanthi, 2007). Penelitian selanjutnya menemukan tidak ada perbedaan yang signifikan antara laki-laki dan perempuan di dalam faktor-faktor kepribadian mereka (Savitha \& Venkatachalam, 2016). Hasil penelitian lain menemukan kebersamaan ayah dan ibu dengan anak-anak mereka; kehangatan; dukungan dan kontrol dari ayah dan ibu memiliki dampak yang berbeda terhadap persepsi anak-anak remaja. Oleh sebab itu, dapat diketahui bahwa perempuan memiliki skor lebih tinggi terhadap persepsi gaya pola asuh orangtua daripada laki-laki (Laible \& Carlo, 2004). Secara umum hasil yang lebih mutualitas; kedekatan; dan kontrol ada dalam hubungan ibu dan anak daripada hubungan ayah dan anak selama masa remaja (Collins \& Russell, 1991). Secara detail, hasil penelitian sebelumnya mengenai jenis kelamin dan big five personality disajikan pada tabel 2 .

Tabel 2 Hasil Penelitian Sebelumnya mengenai Hubungan Jenis Kelamin dan Big Five Personality

\begin{tabular}{|c|c|c|c|c|c|c|c|}
\hline \multirow[t]{2}{*}{ No. } & \multirow{2}{*}{$\begin{array}{c}\text { Big Five } \\
\text { Personality Factors }\end{array}$} & \multicolumn{2}{|c|}{ Laki-Laki (L) } & \multicolumn{2}{|c|}{ Perempuan (P) } & \multirow{2}{*}{$\begin{array}{c}\text { Tidak ada } \\
\text { Perbedaan/ } \\
\text { Sig. } \\
\text { L \& P. }\end{array}$} & \multirow{2}{*}{ Peneliti } \\
\hline & & Tinggi & Rendah & Tinggi & Rendah & & \\
\hline \multirow[t]{4}{*}{1} & Extraversion & & & & & $\sqrt{ }$ & (Bronfenbrenner, 1977) \\
\hline & & & & & & $\sqrt{ }$ & $\begin{array}{l}\text { (Savitha \& } \\
\text { Venkatachalam, 2016) }\end{array}$ \\
\hline & & $\sqrt{ }$ & & & $\sqrt{ }$ & & (Sravanthi, 2007) \\
\hline & & $\sqrt{ }$ & & & $\sqrt{ }$ & & $\begin{array}{l}\text { (Vianello, Schnabel, } \\
\text { Sriram, \& Nosek, 2013) }\end{array}$ \\
\hline \multirow[t]{3}{*}{2} & Conscientiousness & & & & & $\sqrt{ }$ & (Bronfenbrenner, 1977) \\
\hline & & & & & & $\sqrt{ }$ & $\begin{array}{l}\text { (Savitha \& } \\
\text { Venkatachalam, 2016) }\end{array}$ \\
\hline & & $\sqrt{ }$ & & & $\sqrt{ }$ & & (Sravanthi, 2007) \\
\hline \multirow[t]{4}{*}{3} & Openness to & & & & & $\sqrt{ }$ & (Bronfenbrenner, 1977) \\
\hline & $\exp$ & & & & & $\sqrt{ }$ & $\begin{array}{l}\text { (Savitha \& } \\
\text { Venkatachalam, 2016) }\end{array}$ \\
\hline & & $\sqrt{ }$ & & & $\sqrt{ }$ & & (Sravanthi, 2007) \\
\hline & & $\sqrt{ }$ & & & $\sqrt{ }$ & & (Vianello dkk., 2013) \\
\hline \multirow[t]{5}{*}{4} & Neuroticism/ & & & & & $\sqrt{ }$ & (Bronfenbrenner, 1977) \\
\hline & stablity & & & & & $\sqrt{ }$ & $\begin{array}{l}\text { (Savitha \& } \\
\text { Venkatachalam, 2016) }\end{array}$ \\
\hline & & & $\sqrt{ }$ & $\sqrt{ }$ & & & $\begin{array}{l}\text { (Djudiyah, Harding, \& } \\
\text { Sumantri, 2016) }\end{array}$ \\
\hline & & & $\sqrt{ }$ & $\sqrt{ }$ & & & (Vianello dkk., 2013) \\
\hline & & $\sqrt{ }$ & & & $\sqrt{ }$ & & (Sravanthi, 2007) \\
\hline \multirow[t]{5}{*}{5} & Agreeableness & & & & & $\sqrt{ }$ & (Bronfenbrenner, 1977) \\
\hline & & & & & & $\sqrt{ }$ & $\begin{array}{l}\text { (Savitha \& } \\
\text { Venkatachalam, 2016) }\end{array}$ \\
\hline & & & $\sqrt{ }$ & $\sqrt{ }$ & & & (Budaev, 1999) \\
\hline & & & & $\sqrt{ }$ & & & (Vianello dkk., 2013) \\
\hline & & $\sqrt{ }$ & & & $\sqrt{ }$ & & (Sravanthi, 2007) \\
\hline
\end{tabular}


Berkaca pada penelitian-penelitian sebelumnya, perlu dilakukan penelitian ulang untuk mengonfirmasi signifikansi pengaruh pola asuh autoritatif atau demokratis dan jenis kelamin terhadap big five personality factors. Untuk itu tujuan penelitian ini adalah: (1) untuk mengetahui signifikansi pengaruh gaya pola asuh autoritatif terhadap big five personality factors; (2) untuk mengetahui signifikansi pengaruh jenis kelamin terhadap big five personality factors; dan (3) untuk mengetahui signifikansi pengaruh interaksi jenis kelamin dan gaya pola asuh authoritatif terhadap big five personality factors.

\section{METODE}

\section{Desain}

Penelitian ini merupakan penelitian kuantitatif yang menggunakan analisis deskriptif dan statistik inferensial sebagai teknik analisis data. Analisis statistik deskriptif dilakukan dengan mendeskripsikan data yang diperoleh, meliputi nilai rata-rata dan standar deviasi. Analisis statistik inferensial dilakukan untuk menguji masing-masing hipotesis. Pengujian hipotesis pada penelitian ini menggunakan uji MANCOVA dengan bantuan program SPSS 18.0.

\section{Partisipan}

Populasi dalam penelitian ini adalah siswa kelas XI SMA Negeri 2 Kupang tahun ajaran 2018/2019 yang berjumlah 414 siswa, dengan rincian siswa jurusan Ilmu Pengetahuan Sosial sebanyak 165 siswa; siswa jurusan Ilmu Pengetahuan Alam sebanyak 189 siswa; dan siswa jurusan Bahasa sebanyak 60 siswa. Karena populasi yang lebih dari 100 maka sampel yang diambil sebesar $15 \%$ (Arikunto, 2006). Jumlah siswa yang dijadikan sampel adalah 62 siswa, yang meliputi 35 orang laki-laki dan 27 perempuan. Pengambil sampel menggunakan teknik cluster random sampling.

\section{Instrumen}

\section{Parental Authority Questionnaire (PAQ)}

Skala PAQ dikembangkan oleh Buri (Ribeiro, 2009; Smith, 2008) bagi anak remaja untuk mengevaluasi gaya pola asuh orangtua mereka. Skala ini memiliki validitas konstruk alat ukur untuk pola asuh otoriter $(\mathrm{r}=-38, \mathrm{p}<0005)$; pola asuh autoritatif $(\mathrm{r}=-48, \mathrm{p}<0005)$; dan pola asuh permisif $(\mathrm{r}=-$ $50, \mathrm{p}<0005)$, sehingga dapat diketahui bahwa alat ukur ini valid untuk mengukur pola asuh dengan tiga dimensi, yaitu: otoriter; autoritatif; dan permisif. Skala $P A Q$ terdiri 30 butir pernyataan dengan menggunakan skala Likert, setiap dimensi pola asuh diwakili 10 butir pernyataan. Format jawaban $P A Q$ tidak diubah oleh peneliti, yaitu sangat tidak setuju (STS) diberi skor 1; tidak setuju (TS) diberi skor 2; ragu-ragu (R) diberi skor 3; setuju (S) diberi skor 4; sangat setuju (SS) diberi skor 5. Dalam penelitian ini peneliti hanya memakai dimensi autoritatif untuk mengukur pola asuh orangtua yang ada dalam butir nomor: $4 ; 5 ; 8 ; 11 ; 15 ; 20 ; 22 ; 23 ; 27 ; 30$.

\section{International Personality Item Pool (IPIP)}

Skala IPIP dikembangkan oleh Goldberg. Skala ini memiliki validitas faktorial, validitas konvergen dan konsistensi internal yang baik (Indeks Alpha Cronbach mulai dari 0,82 sampai $0,97)$ untuk korelasi lima faktor. IPIP memiliki lima skala yang mengukur: (1) extraversion; (2) agreeableness; (3) conscientiousness; (4) emotional stability/neuroticism; dan (5) openness to experience. Skala IPIP memiliki 50 butir pernyataan yang terdiri dari 10 butir untuk setiap big five personality factors. Skala IPIP menggunakan skala Likert dengan kemungkinan jawaban very inaccurate (1); moderately inaccurate (2); neither inaccurate nor accurate (3); moderately (4); dan very accurate (5). Format jawaban skala IPIP diubah oleh menjadi: sangat tidak setuju (STS) diberi skor 1; tidak setuju (TS) diberi skor 2; ragu-ragu (R) diberi skor 3; setuju (S) diberi skor 4; sangat setuju (SS) diberi skor 5. 


\section{HASIL}

Hasil analisis data deskriptif masing-masing variabel menunjukkan bahwa sebagian besar subjek memiliki tingkat kepribadian emotional stability/neuroticism yang berada pada kategori rendah, yakni 50\% (std deviation 4,244); agreeableness yang berada pada kategori tinggi, yakni $38,3 \%$ (std. deviation 6,480); conscientiousness yang berada pada kategori tinggi, yakni 46,7\% (std deviation 5,081); extraversion yang berada pada kategori rendah, yakni 58\% (std deviation 5,295); dan openness to experience yang berada pada kategori tinggi, yakni 45\% (std deviation 5,598). Sedangkan untuk variabel pola asuh autoritatif orangtua, sebagian besar subjek penelitian berada pada kategori yang sangat tinggi $39 \%$ (std deviation 16,710).

Uji prasyarat dilakukan sebelum uji hipotesis. Uji prasyarat yang pertama dilakukan adalah uji normalitas. Hasil uji normalitas menunjukkan bahwa nilai signifikansi dari uji Kolmogorov-Smirnov sebesar 0,387>0,05 (emotional stability); 0,709>0,05 (agreeableness); 0,636>0,05 (conscientiousness); 0,791>0,05 (extraversion); 0,693 >0,05 (openness to experience), dan 0,592>0,05 (pola asuh autoritatif atau demokratis), sehingga dapat diketahui bahwa data berdistribusi normal seperti yang disajikan pada tabel 3. Dengan demikian, analisis MANCOVA dapat dilanjutkan. Uji prasyarat yang kedua, yaitu Box's Test. Output nilai Box's Test sebesar 5,434 dengan taraf signifikansi 0,673. Berdasarkan kriteria pengujian dengan signifikansi 0,05, maka nilai Box's Test yang diperoleh tidak signifikan karena signifikansi yang diperoleh $0,673>0,05$. Dengan demikian hipotesis nol diterima, berarti matriks kovarian dari variabel dependen sama, sehingga analisis MANCOVA dapat dilanjutkan seperti yang disajikan pada tabel 4. Uji prasyarat ketiga, yaitu uji homogenitas varian. Berdasarkan Levene's Test didapat nilai signifikansi emotional stability 0,392 >0,05; agreeableness $0,937>0,05$; conscientiousness $0,223>0,05$; extraversion $0,192>0,05$; dan openness to experience $0,254>0,05$, hasil Levene's Test secara lebih jelas disajikan pada tabel 5. Dengan melihat hasil Levene's Test, maka dilanjutkan dengan uji MANCOVA.

Hasil analisis MANCOVA menunjukkan bahwa jenis kelamin terhadap emotional stability diperoleh nilai signifikansi 0,136; agreeableness diperoleh nilai signifikansi 0,312; conscientiousness diperoleh nilai signifikansi 0,713 ; extraversion diperoleh nilai signifikansi 0,896 ; dan openness to experience diperoleh nilai signifikansi 0,209 . Semuanya lebih besar dari 0,05 , maka dapat diketahui bahwa tidak ada pengaruh jenis kelamin terhadap big five personality. Untuk pola asuh autoritatif orangtua terhadap emotional stability diperoleh nilai signifikansi 0,854; agreeableness diperoleh nilai signifikansi 0,424; conscientiousness diperoleh nilai signifikansi 0,629; extraversion diperoleh nilai signifikansi 0,000; dan openness to experience diperoleh nilai signifikansi 0,616. Berdasarkan hasil ini, ditemukan bahwa ada pengaruh signifikan pola asuh demokratis orangtua terhadap extraversion dengan nilai signifikansi $0,012<0,05$. Pola asuh demokratis orangtua tidak berpengaruh pada emotional stability; agreeableness; conscientiousness; dan openness to experience karena nilai signifikansi lebih besar dari 0,05 . Untuk interaksi antara jenis kelamin dan pola asuh demokratis orangtua terhadap emotional stability $(0,114>0,05)$; agreeableness $(0,332>0,05)$; conscientiousness

Tabel 3 Uji Normalitas Kolmogorov-Smirnov

\begin{tabular}{cccccc}
\hline Neuroticism & Agreeableness & Conscientiousness & Extraversion & $\begin{array}{c}\text { Openness to } \\
\text { Experience }\end{array}$ & $\begin{array}{c}\text { Pola Asuh } \\
\text { Autoritatif } \\
\text { Orangtua }\end{array}$ \\
\hline 0,387 & 0,709 & 0,636 & 0,791 & 0,693 & 0,592 \\
Normal & Normal & Normal & Normal & Normal & Normal \\
\hline
\end{tabular}

Tabel 4 Uji Box's Test Equality Covariance Matrices

\begin{tabular}{lclcc}
\hline Box's M & F & df1 & df2 & Sig. \\
\hline 13,309 & 0,805 & 15 & 12529,733 & 0,673 \\
\hline
\end{tabular}


Tabel 5 Uji Levene's Test of Equality of Error Variances

\begin{tabular}{lcccc}
\hline & F & df1 & df2 & Sig. \\
\hline Emotional Stability (Y1) & 0,744 & 1 & 60 & 0,392 \\
Agreeableness (Y2) & 0,006 & 1 & 60 & 0,937 \\
Conscientiousness (Y3) & 1,519 & 1 & 60 & 0,223 \\
Extraversion (Y4) & 1,742 & 1 & 60 & 0,192 \\
Openness to Experience (Y5) & 1,326 & 1 & 60 & 0,254
\end{tabular}

Tests the null hypothesis that the error variance of the dependent variable is equal across groups

a. Design: Intercept + Kelamin + PAD + Kelamin * PAD

Tabel 6 Uji Test of Between-Subjects Effect

\begin{tabular}{|c|c|c|c|c|c|c|}
\hline Source & Dependent Variable & $\begin{array}{l}\text { Type III } \\
\text { Sum of } \\
\text { Squares }\end{array}$ & $d f$ & $\begin{array}{l}\text { Mean } \\
\text { Square }\end{array}$ & $\boldsymbol{F}$ & Sig. \\
\hline \multirow[t]{5}{*}{ Corrected Model } & Emotional Stability (Y1) & $56,870^{\mathrm{a}}$ & 3 & 18,957 & 1,055 & 0,375 \\
\hline & Agreeableness (Y2) & $64,442^{\mathrm{b}}$ & 3 & 21,481 & 0,499 & 0,684 \\
\hline & Conscientiousness (Y3) & $14,409^{c}$ & 3 & 4,803 & 0,179 & 0,911 \\
\hline & Extraversion (Y4) & $1620,674^{\mathrm{d}}$ & 3 & 540,225 & 350,770 & 0,000 \\
\hline & Openness to Experience (Y5) & $79,880^{\mathrm{e}}$ & 3 & 26,627 & 0,740 & 0,532 \\
\hline \multirow[t]{5}{*}{ Intercept } & Emotional Stability (Y1) & 613,265 & 1 & 613,265 & 34,139 & 0,000 \\
\hline & Agreeableness (Y2) & 2200,868 & 1 & 2200,868 & 51,126 & 0,000 \\
\hline & Conscientiousness (Y3) & 1671,103 & 1 & 1671,103 & 62,114 & 0,000 \\
\hline & Extraversion (Y4) & 4,751 & 1 & 4,751 & 3,085 & 0,084 \\
\hline & Openness to Experience (Y5) & 1964,348 & 1 & 1964,348 & 54,630 & 0,000 \\
\hline \multirow[t]{5}{*}{ Kelamin } & Emotional Stability (Y1) & 41,140 & 1 & 41,140 & 2,290 & 0,136 \\
\hline & Agreeableness (Y2) & 44,710 & 1 & 44,710 & 1,039 & 0,312 \\
\hline & Conscientiousness (Y3) & 3,678 & 1 & 3,678 & 0,137 & 0,713 \\
\hline & Extraversion (Y4) & 0,026 & 1 & 0,026 & 0,017 & 0,896 \\
\hline & Openness to Experience (Y5) & 57,997 & 1 & 57,997 & 1,613 & 0,209 \\
\hline \multirow[t]{5}{*}{$P A D$} & Emotional Stability (Y1) & 0,612 & 1 & 0,612 & 0,034 & 0,854 \\
\hline & Agreeableness (Y2) & 27,859 & 1 & 27,859 & 0,647 & 0,424 \\
\hline & Conscientiousness (Y3) & 6,365 & 1 & 6,365 & 0,237 & 0,629 \\
\hline & Extraversion (Y4) & 1530,685 & 1 & 1530,685 & 993,880 & 0,000 \\
\hline & Openness to Experience (Y5) & 9,142 & 1 & 9,142 & 0,254 & 0,616 \\
\hline \multirow[t]{5}{*}{ Kelamin * PAD } & Emotional Stability (Y1) & 46,266 & 1 & 46,266 & 2,575 & 0,114 \\
\hline & Agreeableness (Y2) & 41,163 & 1 & 41,163 & 0,956 & 0,332 \\
\hline & Conscientiousness (Y3) & 2,581 & 1 & 2,581 & 0,096 & 0,758 \\
\hline & Extraversion (Y4) & 0,004 & 1 & 0,004 & 0,003 & 0,959 \\
\hline & Openness to Experience (Y5) & 56,408 & 1 & 56,408 & 1,569 & 0,215 \\
\hline \multicolumn{7}{|c|}{ a. $R$ Squared $=0,052($ Adjusted $R$ Squared $=0,003)$} \\
\hline \multicolumn{7}{|c|}{ b. $R$ Squared $=0,025$ (Adjusted $R$ Squared $=-0,025)$} \\
\hline \multicolumn{7}{|c|}{ c. $R$ Squared $=0,009$ (Adjusted $R$ Squared $=-0,042)$} \\
\hline \multicolumn{7}{|c|}{ d. $R$ Squared $=0,948$ (Adjusted $R$ Squared $=0,945)$} \\
\hline \multicolumn{7}{|c|}{ e. $R$ Squared $=0,037$ (Adjusted $R$ Squared $=-0,013)$} \\
\hline
\end{tabular}


$(0,758>0,05)$; extraversion $(0,959>0,05)$; dan openness to experience $(0,215>0,05)$. Hal ini menunjukkan bahwa tidak ada pengaruh interaksi jenis kelamin dan pola asuh autoritatif orangtua terhadap big five personality seperti yang disajikan pada tabel 6 .

Hasil analisis menunjukkan bahwa: (1) hipotesis 1 tidak ada pengaruh signifikan pola asuh autoritatif orangtua terhadap emotional stability; agreeableness; conscientiousness; openness to experience $\left(\mathrm{H}_{\mathrm{a}}\right.$ ditolak \& $\mathrm{H}_{0}$ diterima), kecuali extraversion $\left(\mathrm{H}_{\mathrm{a}}\right.$ diterima \& $\mathrm{H}_{0}$ ditolak); (2) hipotesis 2 tidak ada pengaruh signifikan jenis kelamin terhadap emotional stability; agreeableness; conscientiousness; extraversion; openness to experience $\left(\mathrm{H}_{\mathrm{a}}\right.$ ditolak \& $\mathrm{H}_{0}$ diterima); dan hipotesis 3 tidak ada pengaruh signifikan interaksi jenis kelamin dan pola asuh autoritatif terhadap emotional stability; agreeableness; conscientiousness; extraversion; openness to experience $\left(\mathrm{H}_{\text {a }}\right.$ ditolak \& $\mathrm{H}_{0}$ diterima).

\section{PEMBAHASAN}

\section{Pola Asuh Autoritatif dengan Extraversion}

Hasil penelitian menunjukkan pola asuh autoritatif orangtua berpengaruh pada extraversion. Hasil penelitian ini membuktikan bahwa peran gaya pola asuh autoritatif orangtua memiliki pengaruh terhadap kepuasan hidup anak. Anak akan merasa bahagia dalam hidup mereka ketika orangtua mereka menunjukkan kasih dan dukungan secara konsisten. Sebuah studi menunjukkan bahwa ada pengaruh pola asuh autoritatif terhadap kepuasan hidup (Suldo \& Huebner, 2004). Hidup yang berkualitas dan bahagia mengindikasikan siswa telah mengalami kepuasan hidup; kepuasan terhadap kondisi yang dicita-citakan; kondisi luar yang biasa; perasaan bahagia; dan kepuasan terhadap hal-hal yang dianggap penting (Dami, Tameon, \& Alexander, 2018). Pola asuh autoritatif orangtua juga memberikan dukungan kepada sikap suka berteman dari extraversion, bahkan orangtua dengan gaya autoritatif mampu memimpin anak mereka untuk menyesuaikan diri secara baik dalam komunitas walaupun anak berasal dari budaya individualistik karena anak-anak yang diasuh menggunakan gaya autoritatif menerima dukungan dan pertolongan dari orangtua mereka dalam pengembangan kompetensi sosial mereka (Kazemi, Ardabili, \& Solokian, 2010). Kehangatan dan dukungan dari orangtua yang autoritatif sangat penting dalam meningkatkan self-esteem dan sikap positif anak. Dengan self-esteem yang tinggi dan sikap positif, anak mampu berinteraksi dengan orang lain karena mereka memiliki kepercayaan diri untuk bersama dengan orang lain (Lamborn, Mounts, Steinberg, \& Dornbusch, 1991). Penelitian sebelumnya menegaskan bahwa extraversion berhubungan positif dengan perasaan yang baik tentang hidup. Extraversion memberikan pengaruh positif yang lebih besar di dalam hidup setiap hari. Kondisi seperti ini diciptakan oleh gaya pola asuh autoritatif orangtua (Edobor \& Ekechukwu, 2015).

Siswa tipe extraversion perlu mendapat perhatian khusus dari konselor karena hasil penelitian sebelumnya menunjukkan bahwa siswa tipe extravesion cenderung mengalami kebimbangan dalam mengambil keputusan kariernya. Hal ini dikarenakan siswa tipe extraversion tertarik dengan banyak hal yang akan menyebabkan mereka cepat dan mudah merubah pilihan (Utami dkk., 2018). Siswa tipe extraversion juga cenderung cinta diri sendiri secara berlebihan (narsistik). Di dalam aspek ini, siswa tipe extraversion suka berteman untuk mempertinggi status dirinya, membuat kesan yang mempesona (kehangatan); menonjolkan diri; memiliki sikap impulsif yang tinggi, mencari keuntungan; mencari perhatian; dan memamerkan kehebatannya (asertif) sehingga cenderung melanggar etika dan membuat keputusan yang beresiko tanpa berpikir panjang (mencari kesenangan) (Hardiani, 2014). Siswa dengan kecenderungan kepribadian extraversion cocok dengan gaya konseling cognitive. Semakin siswa cenderung memiliki kepribadian yang hangat; suka bergaul; asertif; aktif dan suka mencari kesenangan, maka semakin menyukai gaya konseling yang fokus pada keyakinannya dan berupaya memodifikasinya hingga lebih efektif lagi (Erickson, 1993). Efektif yang dimaksudkan di sini adalah efektif dalam membuat keputusan karier dan efektif dalam menampilkan pergaulan yang positif dengan siapapun khususnya teman sebaya di sekolah. Hasil 
penelitian ini relevan dengan temuan penelitian sebelumnya (Dordi \& Pol, 2018; Kilonzo, 2017; Mize \& Pettit, 1997), sebaliknya berbeda dengan beberapa temuan lainnya (Ghani dkk., 2014; Maddahi dkk., 2012; Savitha \& Venkatachalam, 2016).

\section{Pola Asuh Autoritatif dengan Conscientiousness}

Pola asuh autoritatiforangtuamemilikipengaruhyangtidaksignifikanterhadap conscientiousness. Hal ini mengindikasikan bahwa pola asuh autoritatif mempunyai kekurangan sehingga tidak memberi dampak yang signifikan kepada siswa dengan tipe kepribadian conscientiousness. Tipe kepribadian conscientiousness menggambarkan keteraturan siswa; tekun; dan motivasi yang berorientasi pada tujuan. Siswa tipe conscientiousness adalah siswa yang rasional; berpusat pada informasi; dan secara umum berpikir bahwa mereka adalah orang yang kompeten. Bagian dari kesuksesan mereka merupakan hasil dari keteraturan dan keurutan yang membuat mereka efisien dalam bekerja. Mereka sangat berpusat pada tugas/kewajiban. Mereka unggul dalam pencapaian prestasi; mengejar keunggulan dalam setiap hal yang mereka lakukan; mereka pun memiliki disiplin tinggi yang membuat mereka dapat mencapai tujuannya. Selain itu, mereka juga pandai membuat rencana yang canggih dan memikirkannya dengan hati-hati sebelum bertindak. Perpaduan antara kompetensi; pencapaian prestasi; dan keteraturan ini mengindikasikan karakteristik siswa yang perfeksionis dan ambisius. Dampaknya, mereka memiliki perasaan hebat bahwa dirinya adalah orang penting dan berperilaku sombong (Pervin \& John, 2001).

Kebanyakan dari siswa yang memiliki kencenderungan kepribadian conscientiousness adalah siswa yang mengalami masalah dengan penerapan pola asuh orangtua di rumah (Sonita, 2013). Oleh karena itu, orangtua yang menerapkan pola asuh autoritatif perlu memahami bahwa siswa dengan kecenderungan kepribadian conscientiousness perlu memperoleh layanan bantuan dengan gaya konseling cognitive. Siswa yang merasa dirinya kompeten; memiliki perencanaan yang bagus dan rapi; taat pada prinsip dan etika; selalu ingin mencapai prestasi lebih tinggi; memiliki disiplin diri; serta penuh pertimbangan akan menyukai gaya konseling cognitive yang akan menunjukkan keyakinan tidak benar dan mengajaknya untuk memodifikasi keyakinan tersebut agar dapat lebih efektif mencapai apa yang diinginkan (Crockett \& Crawford, 1989). Di dalam konteks ini, siswa membutuhkan disiplin bila mereka ingin bahagia dan menjadi orang yang baik penyesuaiannya. Melalui disiplin, mereka dapat belajar berperilaku dengan cara yang diterima masyarakat dan sebagai hasilnya mereka akan diterima oleh anggota kelompok sosial (Fiana, Daharnis, \& Ridha, 2013). Layanan bimbingan pribadi perlu dilakukan juga oleh konselor, agar siswa memiliki disiplin diri (Wangid, 2010) sehingga para siswa menjadi lebih positif dan mampu mengarahkan diri dalam pendidikan dan kehidupan, serta berusaha keras mencapai tujuan masa depannya (American School Counselor Association, 2016). Hasil penelitian ini sejalan dengan temuan sebelumnya (Ghani dkk., 2014; Savitha \& Venkatachalam, 2016; Turner dkk., 2009), sebaliknya, hasil juga berbeda dengan beberapa penelitian sebelumnya (Dordi \& Pol, 2018; Maddahi dkk., 2012).

\section{Pola Asuh Autoritatif dengan Openness to Experience}

Hasil penelitian menunjukkan bahwa tidak ada pengaruh yang signifikan dari pola asuh autoritatif terhadap openness to experience. Pola asuh autoritatif kurang tepat untuk membimbing siswa dengan tipe kepribadian openness to experience. Siswa tipe openness to experience adalah siswa yang menilai usahanya secara proaktif dan memberi penghargaan terhadap pengalaman demi kepentingannya sendiri. Mereka menggali sesuatu yang baru dan tidak biasa. Siswa dengan keterbukaan terhadap pengalaman memiliki karakteristik mudah toleransi; mudah menyerap informasi; fokus; kreatif; imajinatif; dan berpikir luas. Karakteristik tersebut memberikan peluang siswa dengan tipe openness to experience terhadap pengalaman untuk mencari sensasi dan impulsif. Indikator imajinatif mengindikasikan bahwa siswa memiliki kemampuan mengkhayalkan sesuatu yang tinggi. Selain itu, indikator estetika pada tipe kepribadian openness to experience terhadap pengalaman mengindikasikan individu dengan artistic experience, menyukai seni dan keindahan. 
Indikator ini mengindikasikan keterlibatan seseorang dalam sensasi dan persepsi. Berdasarkan orientasi ini, siswa tipe openness to experience dapat terjebak di dalam fantasi-fantasi tentang kesuksesan; kekuasaan; kecerdasan; kecantikan; atau cinta ideal tanpa batas (Hardiani, 2014). Siswa yang suka berfantasi, memiliki minat yang tinggi pada kesenian, menunjukkan keterbukaan pada perasaan yang dialami, suka mencoba pengalaman yang baru, terbuka pada pemikiran baru, terbuka pada nilai-nilai baru serta ingin mengujinya akan sangat menyukai gaya psychoanalitic yang akan mengajak mereka mengeksplorasi kembali masa kecil dengan membuat interpretasi ulang dan merekonstruksi ulang, yang bisa jadi adalah hal yang baru baginya (Miller, 1991). Selain gaya konseling psychoanalitic, gaya konseling client centered yang memberi perhatian pada penerimaan membuat siswa mampu memiliki kecenderungan openness to experience siap untuk menerima pemikiran; ide; nilai yang baru.

Seorang siswa yang berpikir kreatif mengenai masa depan dapat menemukan jurusan yang tepat baginya, dan akan lebih cepat menentukanjurusan dalam proses pengambilan keputusan dibandingkan siswa yang tidak memiliki ciri karakteristik openness to experience. Oleh karena itu, siswa SMA yang memiliki ciri kepribadian ini cenderung tidak mudah untuk mengalami kebimbangan karier. Karena ciri kepribadian ini mampu mencari informasi baru terkait pilihan jurusan atau program studi yang akan dipilihnya. Siswa tipe openness to experience memiliki pemahaman akan layanan informasi karier yang digunakan sebagai bahan acuan dalam meningkatkan kegiatan dan prestasi belajar; mengembangkan cita-cita; menyelenggarakan kehidupan sehari-hari dan mengambil suatu keputusan (Hidayati, 2015). Hasil penelitian ini menunjukkan kesamaan dengan penelitian yang telah lalu (Ghani dkk., 2014; Maddahi dkk., 2012), sebaliknya berbeda dengan beberapa penelitian lain (Dordi \& Pol, 2018; Farbstein, 2011; Savitha \& Venkatachalam, 2016).

\section{Pola Asuh Autoritatif dengan Emotional Stability/ Neuroticism}

Hasil penelitian menunjukkan bahwa pola asuh autoritatif tidak memberikan pengaruh yang signifikan terhadap emotional stability/neuroticism. Siswa dengan tipe kepribadian emotional stability/ neuroticism perlu memperoleh layanan bantuan yang lebih profesional, tidak cukup dengan pola asuh autoritatif. Siswa dengan tipe kepribadian emotional stability/ neuroticism sangat mudah terluka dengan suatu kritik dan sadar akan keadaan dirinya namun kadang-kadang mereka juga menyangkal keadaan dirinya, juga berbagai macam kekurangan dirinya atau kecemasan yang sedang dialaminya (Miller, Widiger, \& Campbell, 2010). Siswa dalam kategori emotional stability/ neuroticism adalah siswa yang: agresif; emosi negatif; dan mudah marah ketika menerima perilaku yang negatif dari orangtua, bahkan mereka dapat menimbulkan gaya ketegasan yang kuat (kurang responsif, lebih authoritarian) dari orangtua mereka (Bahrami dkk., 2017). Siswa seperti ini akan mengalami masalah psikologis atau psikososial, seperti sulit berkosentrasi; cemas; dan gejala perilaku menyimpang (Wibowo, 2017). Di pihak lain, siswa dengan ciri kepribadian neuroticsm yang tinggi mengambil keputusan disertai keragu-raguan dan takut gagal. Siswa SMA dengan ciri-ciri kepribadian neuroticism ketika memilih jurusan cenderung kurang yakin; merasa khawatir; cemas; kurang mampu dalam menentukan beberapa pilihan program studi yang akan dipilihnya (Utami dkk., 2018).

Siswa yang memiliki kecenderungan kepribadian neuroticism perlu mendapat layanan konseling dengan gaya konseling psychoanalic dan client centered. Hal ini dikarenakan pendekatan konseling psychoanalitic berupaya membantu siswa untuk mengatasi konflik unconsciousness, mengembangkan cara yang lebih memuaskan untuk menyelesaikan masalah dan menganalisa ulang masa kecil serta merekonstruksinya. Demikian pula pendekatan client centered yang fokus dalam memahami siswa daripada sibuk mendiagnosa, memberi nasehat atau mempersuasi. Sebaliknya siswa yang neurotis tentu tidak menyukai gaya konseling yang lebih memperhatikan keyakinan yang dibawanya dan berusaha untuk memodifikasinya (Sharf, 2015). Hasil penelitian ini senada dengan hasil penelitian sebelumnya (Abdi dkk., 2010; Bahrami dkk., 2017; Ghani dkk., 2014), namun berbeda dengan beberapa penelitian yang lain (Savitha \& Venkatachalam, 2016; Sravanthi, 2007). 


\section{Pola Asuh Autoritatif dengan Agreeableness}

Hasil penelitian menunjukkan tidak ada pengaruh yang signifikan dari pola asuh autoritatif terhadap agreeableness. Bercermin dari hasil penelitian ini, konkritnya orangtua dalam menjalankan peran pola asuh autoritatifnya terhadap big five personality factors, tidak dapat berperan secara single fighter, tetapi haruslah berkolaborasi dengan konselor sekolah, agar siswa (konseli) sebagaimana yang diharapkan oleh konselor dapat menjalani proses perkembangan sesuai dengan tahap-tahap perkembangan agar mencapai perkembangan yang optimal; mandiri; bahagia; dan sejahtera yang senada dengan minat mereka dalam menjalani berbagai kehidupan (American School Counselor Association, 2012; Wibowo, 2017). Siswa yang memiliki kecenderungan kepribadian agreeableness, menunjukkan keterusterangan; altruis; rela untuk mengalah; sederhana dan lembut hati menyukai gaya konseling client centered yang membawa siswa pada pemahaman serta penerimaan diri sendiri dan orang lain (Barber \& Stoltenberg, 1994). Dalam kaitan dengan pengambilan keputusan karier, siswa agreeableness lebih mudah mengambil keputusan karier. Mereka lebih terbuka kepada pengalaman dan pembelajaran baru yang membuat mereka lebih cenderung mengeksplorasi alternatif-alternatif karier dan menemukan karier yang paling cocok dengan mereka. Mereka juga lebih terbuka menerima masukan dari konselor dan sumber-sumber informasi lainnya (Lounsbury dkk., 2005). Siswa yang dengan ciri kepribadian seperti ini disukai, diperhatikan dan dibantu oleh konselor di dalam area pilihan karier karena mereka kooperatif (Wentzel, 1993).

Konselor dapat meningkatkan kepercayaan diri siswa agreeableness melalui konseling kelompok. Konseling kelompok terbukti mampu meningkatkan percaya diri siswa (Imro'atun, 2017), dimana siswa dapat secara bebas mengutarakan pendapatnya karena situasi dan kondisi kegiatan dirancang secara sistematis, sehingga siswa merasa aman dan nyaman menguratakan persoalannya, maupun alternatif dan argumentatif (Marjanti, 2015). Hasil penelitian ini sejalan dengan beberapa penelitian yang telah dilakukan (Ghani dkk., 2014; Maddahi dkk., 2012; Savitha \& Venkatachalam, 2016), tetapi berbeda dari temuan menyatakan ada hubungan antara pola asuh autoritatif terhadap agreeableness (Kilonzo, 2017; Sravanthi, 2007).

\section{Jenis Kelamin dengan Big Five Personality Factors}

Hasil penelitian menemukan bahwa tidak ada pengaruh yang signifikan jenis kelamin terhadap extraversion; emotional stability; agreeableness; conscientiousness; serta openness to experience. Hasil penelitian ini menguatkan temuan yang menyatakan bahwa jenis kelamin tidak memiliki pengaruh yang signifikan pada semua faktor big five personality (Savitha \& Venkatachalam, 2016). Tidak adanya pengaruh jenis kelamin dipengaruhi oleh budaya; sub budaya dan kelas sosial; atau yang disebut macro system (Bronfenbrenner, 1977). Setiap orang dipengaruhi oleh jenis informasi yang sama melalui media masa dan monoculture pada level macro system. Dengan demikian konsep persamaan diutamakan, sehingga perbedaan jenis kelamin dalam kepribadian dibatasi di antara para siswa.

Penelitian ini perlu ditindaklanjuti oleh karena dalam penelitian ini peneliti hanya menggunakan salah satu aspek dari pola asuh orangtua, yaitu autoritatif. Penelitian akan menjadi lebih komprehensif dan holistik jika beberapa jenis pola asuh seperti autoritarian; permissive, dan neglectful, sehingga dapat mengetahui pola asuh mana yang secara spesifik lebih dominan memengaruhi big five personality factors.

\section{SIMPULAN}

Hasil penelitian menunjukkan bahwa: (1) ada pengaruh signifikan pola asuh autoritatif orangtua terhadap extraversion subjek, namun tidak ada pengaruh signifikan pola asuh autoritatif orangtua terhadap emotional stability/neuroticism; agreeableness; conscientiousness; dan openness to experience subjek; (2) tidak ada pengaruh signifikan jenis kelamin terhadap big five personality subjek; serta (3) tidak ada pengaruh signifikan interaksi jenis kelamin dan pola asuh autoritatif terhadap big five personality pada subjek. 


\section{DAFTAR RUJUKAN}

Abdi, M., Jalali, A., \& Mirmehdy, R. (2010). An investigation and Comparison of Personality Traits and The Study of Parenting Rearing of 12-18 Delinquency and Non-delinquency Youth. Procedia-Social and Behavioral Sciences, 5, 2089-2092.

Amalia, R. N. (2017). Hubungan Pola Asuh Demokratis Orang Tua dengan Kemampuan Pengambilan Keputusan Karir Pada Siswa Kelas XI di SMA N 8 Semarang. Universitas Negeri Semarang.

Anggraini, A., Hartuti, P., \& Sholihah, A. (2018). Hubungan Pola Asuh Orang Tua dengan Kepribadian Siswa SMA di Kota Bengkulu. Consilia : Jurnal Ilmiah Bimbingan dan Konseling, 1(1), 10-18.

Antoni, Y. (2014). Pengaruh Gaya Pengasuhan Orang Tua dan Komunikasi Interpersonal GuruSiswa terhadap Kedisiplinan Siswa pada Peraturan Tata Tertib Sekolah di Kelas XI dan XII SMK YPKK 3 Sleman. (Skripsi tidak diterbitkan) Universitas Negeri Yogyakarta.

Arikunto, S. (2006). Prosedur Penelitian Suatu Pendekatan Praktek. Jakarta: PT Rineka Cipta.

American School Counselor Association. (2012). ASCA School Counselor Competencies. Diambil November 13, 2015, dari https://www.schoolcounselor.org/asca/media/asca/home/ SCCompetencies.pdf

American School Counselor Association. (2016). Ethical Standards for School Counselors. The School Counselor. JSTOR.

Bahrami, B., Dolatshahi, B., Pourshahbaz, A., \& Mohammadkhani, P. (2017). Determinants of Authoritative Parenting Style in Iranian Mothers. Iranian Rehabilitation Journal, 15(4), 317 324.

Baldwin, D. R., McIntyre, A., \& Hardaway, E. (2007). Perceived Parenting Styles on College Students' Optimism. College Student Journal, 41(3), 550-558.

Barber, L. C., \& Stoltenberg, C. D. (1994). Preference for Counseling Approach as A Function of Emotional Locus of Control and Personal Relevance. Journal of Social and Clinical Psychology, 13(3), 240-251.

Bronfenbrenner, U. (1977). Toward an Experimental Ecology of Human Development. American Psychologist, 32(7), 513-531. https://doi.org/10.1037/0003-066X.32.7.513

Budaev, S. V. (1999). Sex Differences in The Big Five Personality Factors: Testing An Evolutionary Hypothesis. Personality and Individual Differences, 26(5), 801-813.

Collins, W. A., \& Russell, G. (1991). Mother-child and Father-child Relationships in Middle Childhood and Adolescence: A Developmental Analysis. Developmental Review, 11(2), 99-136.

Crockett, J. B., \& Crawford, R. L. (1989). The Relationship between Myers-Briggs Type Indicator (MBTI) Scale Scores and Advising Style Preferences of College Freshmen. Journal of College Student Development, 30(2), 154-161.

Dami, Z. A., Tameon, S. M., \& Alexander, F. (2018). Spiritual Well-being as Variable Intervening Mindfulness dan Life Satisfaction. Konselor, 7(4), 124-137. https://doi. org/10.24036/0201874102383-0-00

Dariyo, A. (2003). Psikologi Perkembangan Dewasa Muda. Jakarta: Grasindo.

Desmita, D. (2011). Psikologi Perkembangan Peserta Didik: Panduan Bagi Orang Tua dan Guru Dalam Memahami Psikologi Anak Usia SD, SMP, dan SMA. Bandung: Remaja Rosdakarya.

Diponegoro, A. M. (2013). Hubungan Pola Asuh Otoritatif, Kontrol Diri, Ketrampilan Komunikasi dengan Agresivitas Siswa. Psikopedagogia: Jurnal Bimbingan Dan Konseling, 2(2), 101-115.

Djamarah, S. B. (2014). Pola Asuh Orang Tua dan Komunikasi dalam Keluarga. Jakarta: Rineka Cipta.

Djudiyah, M. S., Harding, D., \& Sumantri, S. (2016). Gender Differences in Neuroticism on College Students. Dalam Asean Conference 2nd Psychology \& Humanity (hal. 723-728). 
Dordi, M. M., \& Pol, M. S. (2018). Relationship of Parenting Styles with Personality and Academic Motivation among Adolescents. International Journal of Indian Psychology, 6(1), 152-159.

Edobor, O. J., \& Ekechukwu, R. (2015). Influence of Personality and Social Factors on Delinquent Behaviour Among Secondary School Adolescents in Rivers State. Pyrex Journal of Educational Researchand Reviews, 1(7), 62-67.

Erickson, D. B. (1993). The Relationship Between Personality Type and Preferred Counseling Model. Journal of Psychological Type, 27, 39-41.

Farbstein, J. (2011). Does Social Support Impact the Prediction of Locus of Control for University Students Differentiated on Personality and Parenting?. (Tesis tidak diterbitkan) University of Wisconsin-Stout

Fiana, F. J., Daharnis, D., \& Ridha, M. (2013). Disiplin Siswa di Sekolah dan Implikasinya dalam Pelayanan Bimbingan Dan Konseling. Konselor, 2(23), 26-33.

Frazier, L. R. (2018). The Effect of Parenting Style on A Child in Relation to Personality Traits as A Young Adult. The Chicago School of Professional Psychology.

Garcia, Q. P., \& Santiago, A. B. B. (2017). Parenting Styles as Correlates to Self-esteem of Underprivileged Adolescents: Basis For A Proposed Parenting Skills Program. Parenting, 2(5), 27-35.

George, J. M., \& Jones, G. R. (1996). Organizational Behaviour: Understanding and Managing. Addison-Wesley Publishing Company.

Ghani, F. B. A., Roeswardi, S. I. bt, \& Aziz, A. bt A. (2014). Parenting Styles and Their Relation to Teenagers' Personality Profile in Single Mother Families: A Case Study. Procedia - Social and Behavioral Sciences, 114, 766-770. https://doi.org/10.1016/j.sbspro.2013.12.782

Hardiani, R. (2014). Hubungan Berbagai Tipe Kepribadian dalam Big Five Factor Personality dengan Perilaku Narsistik Siswa Kelas X SMA Muhammadiyah 2 Yogyakarta Tahun 2014. (Skripsi tidak diterbitkan) Universitas Negeri Yogyakarta.

Hidayanti, W. (2017). Peranan Orang Tua dengan Pola Asuh Demokratis terhadap Prestasi Anak di Desa Sipatuhu Kecamatan Banding Agung Kabupaten Oku Selatan. (Skripsi tidak diterbitkan Universitas Islam Negeri Raden Intan Lampung.

Hidayati, R. (2015). Layanan Informasi Karir Membantu Peserta Didik dalam Meningkatkan Pemahaman Karir. Jurnal Konseling Gusjigang, 1(1).

Imro'atun, S. (2017). Keefektifan Layanan Konseling Kelompok untuk Meningkatkan Kepercayaan Diri Siswa Sekolah Menengah Pertama. Jurnal Kajian Bimbingan dan Konseling, 2(2), 50-57. https://doi.org/10.17977/um001v2i22017p050

Kazemi, A., Ardabili, H. E., \& Solokian, S. (2010). The Association Between Social Competence in Adolescents and Mothers' Parenting Style: A Cross Sectional Study on Iranian Girls. Child and Adolescent Social Work Journal, 27(6), 395-403.

Kilonzo, P. M. (2017). The Impact of Parenting Styles on Personality Dimensions of Adolescents in Public Secondary Schools: A Case of Mombasa County, Kenya. International Journal of Education and Research, 5(7), 263-276.

Laible, D. J., \& Carlo, G. (2004). The Differential Relations of Maternal and Paternal Support and Control to Adolescent Social Competence, Self-worth, and Sympathy. Journal of Adolescent Research, 19(6), 759-782.

Lamborn, S. D., Mounts, N. S., Steinberg, L., \& Dornbusch, S. M. (1991). Patterns of Competence and Adjustment among Adolescents from Authoritative, Authoritarian, Indulgent, and Neglectful Families. Child Development, 62(5), 1049-1065.

Lounsbury, J. W., Hutchens, T., \& Loveland, J. M. (2005). An Investigation of Big Five Personality Traits and Career Decidedness among Early and Middle Adolescents. Journal of Career Assessment, 13(1), 25-39. 
Maddahi, M. E., Javidi, N., Samadzadeh, M., \& Amini, M. (2012). The Study of Relationship Between Parenting Styles and Personality Dimensions in Sample of College Students. Indian Journal of Science and Technology, 5(9), 3332-3336.

Marjanti, S. (2015). Upaya Meningkatkan Rasa Percaya Diri Melalui Konseling Kelompok bagi Siswa XII IPS 6 SMA 2 Bae Kudus Tahun Pelajaran 2014/2015. Jurnal Konseling Gusjigang, 1(2).

Miller, J. D., Widiger, T. A., \& Campbell, W. K. (2010). Narcissistic Personality Disorder and The DSM-V. Journal of Abnormal Psychology, 119(4), 640-649.

Miller, T. R. (1991). The Psychotherapeutic Utility of The Five-factor Model of Personality: A Clinician's Experience. Journal of Personality Assessment, 57(3), 415-433.

Mize, J., \& Pettit, G. S. (1997). Mothers' Social Coaching, Mother-child Relationship Style, and Children's Peer Competence: Is The Medium The Message? Child Development, 68(2), 312323.

Mullins, L. J. (2007). Management and Organisational Behaviour. Pearson Education.

Pervin, L. A., \& John, O. P. (2001). Handbook of Personality: Theory and Research. Elsevier.

Purwanta, E. (2012). Faktor yang Memengaruhi Eksplorasi Karier Siswa SLTP. Cakrawala Pendidikan, 31(2), 228-243.

Rahayu, L. P. (2018). Pengaruh Pola Asuh Orang Tua dan Kontrol Diri Terhadap Perilaku Agresif pada Remaja SMP Negeri 27 Samarinda. Psikoborneo, 6(2), 317-329.

Ramadhani, H. R., Anward, H. H., \& Rachmah, D. N. (2016). Peranan Lima Besar Kepribadian terhadap Kecenderungan Buli pada Remaja. Jurnal Ecopsy, 1(3), 120-125.

Raza, S. A., \& Shah, N. (2017). Influence of the Big Five Personality Traits on Academic Motivation Among Higher Education Students: Evidence from Developing Nation. University Library of Munich, Germany.

Respati, W. S., Yulianto, A., \& Widiana, N. (2006). Perbedaan Konsep Diri antara Remaja Akhir yang Mempersepsi Pola Asuh Orang Tua Authoritarian, Permissive, dan Authoritative. Jurnal Psikologi, 4(2), 119-138.

Ribeiro, L. L. (2009). Construction and Validation of A Four Parenting Styles Scale. (Tesis tidak diterbitkan) Humboldt State University.

Rosito, A. C. (2018). Eksplorasi Tipe Kepribadian Big Five Personality Traits Dan Pengaruhnya Terhadap Prestasi Akademik. Jurnal Psikologi Pendidikan dan Konseling: Jurnal Kajian Psikologi Pendidikan dan Bimbingan Konseling, 4(1), 6-13. https://doi.org/10.26858/jpkk. v4i1.3250

Safitri, Y. (2012). Hubungan antara Persepsi Pola Asuh Demokratis dengan Pemilihan Karir pada Siswa Kelas XI SMA Negeri 11 Yogyakarta. (Skripsi tidak diterbitkan) Universitas Negeri Yogyakarta.

Savitha, K., \& Venkatachalam, J. (2016). Perceived Parenting Styles and Personality Factors-A Study. International Journal of Indian Psychology, 3(4), 21-33.

Septiani, W. (2017). Hubungan Pola Asuh Demokratis dan Konsep Diri terhadap Perkembangan Kecerdasan Emosional. Indonesian Journal of Guidance and Counseling: Theory and Application, 6(3), 22-26.

Sharf, R. S. (2015). Theories of Psychotherapy \& Counseling: Concepts and Cases. Cengage Learning.

Sjarkawi. (2008). Pembentukan Kepribadian Anak: Peran Moral, Intelektual, Emosional, dan Sosial sebagai Wujud Integritas Membangun Jati Diri. Bumi Aksara.

Smith, S. J. (2008). A Descriptive Study of Parenting Styles, Parental Feeding Behaviors and BMI Percentiles in School-Age Children and Adolescents. (Tesis tidak diterbitkan) Wright State University. 
Sonita, S. (2013). Hubungan antara Pola Asuh Orangtua dengan Disiplin Siswa di Sekolah. Konselor, 2(1), 174-181. https://doi.org/10.24036/0201321886-0-00

Sravanthi, S. (2007). Effect of Parenting Styles on Personality Development of Adolescents. Acharya $\mathrm{Ng}$ Ranga Agricultural University, Rajendranagar, Hyderabad.

Suldo, S. M., \& Huebner, E. S. (2004). The Role of Life Satisfaction in The Relationship between Authoritative Parenting Dimensions and Adolescent Problem Behavior. Social Indicators Research, 66(1-2), 165-195.

Sunaryanti, S. S. H. (2016). Hubungan Pola Asuh Orang Tua dengan Kenakalan Remaja Di SMA Negeri 8 Surakarta. IJMS-Indonesian Journal On Medical Science, 3, 38-47.

Turner, E. A., Chandler, M., \& Heffer, R. W. (2009). The Influence of Parenting Styles, Achievement Motivation, and Self-efficacy on Academic Performance in College Students. Journal of College Student Development, 50(3), 337-346.

Utami, S. A., Grasiaswaty, N., \& Akmal, S. Z. (2018). Hubungan Tipe Kepribadian Berdasarkan Big Five Theory Personality dengan Kebimbangan Karier pada Siswa SMA. Journal Psikogenesis, 6(1), 11-18.

Vianello, M., Schnabel, K., Sriram, N., \& Nosek, B. (2013). Gender Differences in Implicit and Explicit Personality Traits. Personality and Individual Differences, 55(8), 994-999.

Wangid, M. N. (2010). Peran Konselor Sekolah dalam Pendidikan Karakter. Cakrawala Pendidikan, 29(3), 173-186.

Wentzel, K. R. (1993). Does Being Good Make The Grade? Social Behavior and Academic Competence in Middle School. Journal of Educational Psychology, 85(2), 357-364.

Wibowo, M. E. (2017). Profesi Konselor dalam Kurikulum 2013 dan Permasalahannya. Jurnal Bimbingan dan Konseling Terapan, 1(2), 63-85. https://doi.org/10.30598/jbkt.v1i2.143

Wiyani, N. A. (2014). Buku Ajar Penanganan Anak Usia Dini Berkebutuhan Khusus. Yogyakarta: Ar-Ruzz Media. 